\title{
DETERMINATION OF STRESS AND STRAIN CONCENTRATIONS IN THE ELASTIC-PLASTIC MATERIALS UNDER BENDING AND TORSION
}

\author{
M. KUREK, T. ŁAGODA, P. WARMUZEK \\ Opole University of Technology, Poland
}

The analysis of stress and strain concentrations of constructional materials subjected to bending and torsion is presented. The known methods of stress determination for any elastic-plastic material assume the linear strain concentration under bending and torsion. Determination of stress and strain concentrations and their presentation as graphs were the main aims of this paper. Five materials were tested. They had different cyclic strain curves, and were loaded by the torsional and bending moments. The results proved a linear character of the strain distribution for any material in the all applied loading range.

Keywords: stress, strain, bending, torsion, cyclic loadings.

A precise determination of the fatigue life requires the determination of stress and strain distribution in the specimen section, or in the element in the regions of elastic-plastic strains. Thus, we obtain the stresses on the surface and distribution of stresses and strains used for the non-local models which more and more often occur at present $[1,3]$. In literature the present state-of-the-art, the character of the elastic-plastic strains distribution under bending and torsion are not explained. The known methods of stress determination for elastic-plastic materials assume the linear strain distribution under bending and torsion [7, 8]. In [5] it was found that the presented models of determination of stresses and strains from the known elastic stresses using the methods proposed by Neuber [10], Molski-Glinka [9], and Lagoda-Macha [6] give incorrect results for bending.

Occurrence of stress and strain gradients causes serious difficulties in determination of the fatigue life under bending, torsion and combined bending and torsion [4]. Precise determination of stress and strain distribution requires numerical calculations (for example FEM - the finite element method), so the approximate analytic equations are often applied.

According to [5], during determination of local stresses and strains under bending, the normal stresses and strains occurring in both elastic and elastic-plastic models must compensate the given bending moment, i.e.

$$
M_{g}=\int_{S} \sigma(x, y) x d S
$$

Under torsion, like under bending, the basic relationship which must be satisfied says that the shear strain occurring in both elastic and elastic-plastic models, should compensate the given torsional model, i.e.

$$
M_{s}=\int_{S} \tau(x, y) x d S .
$$

In this paper, FEM was applied for determination of stress and strain distribution in the specimens with different material characteristics under loading with torsional and bending moments. The results were applied for evaluation of the range of linear strain

Corresponding author: M. KUREK, e-mail: m.kurek@doktorant.po.edu.pl 
distributions under bending and torsion versus loading, and material character as well as the influence of the material properties on the stress distributions.

The used materials. Five materials with different cyclic strain curves were analyzed. The following parameters were taken into account while selecting the material: $E$ (Young's modulus), $K^{\prime}$ (coefficient of cyclic strength) and $n^{\prime}$ (exponent of cyclic hardening). Such selection of the materials allowed to determine the character of stress and strain courses for many materials of a similar characteristic $\sigma_{a}-\varepsilon_{a}$.

Table presents properties of the con-

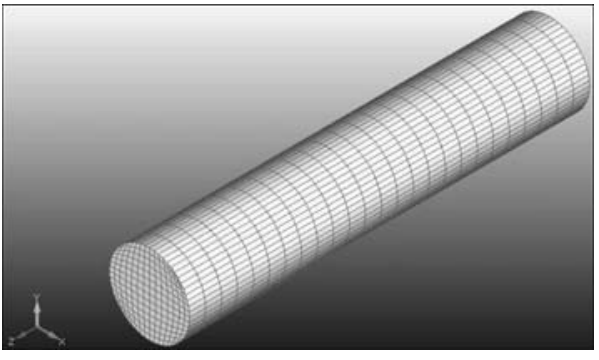

Fig. 1. Isometric view of the FEM model of a cylindrical specimen.

sidered materials. The calculations were done for a circular section bar (Fig. 1) of the radius $r=5 \mathrm{~mm}$ and length $l=50 \mathrm{~mm}$, and were realized with the program FEMAP with NX Nastran 9.3.1. The considered bar was loaded by the torsional moment, bending moment or combination of these moments. The applied loading caused in the external layers the stresses close to the maximum ones at which the specimens were tested. Under bending with torsion, the loading was divided into two equal bending and torsional moments.

\section{Numerical calculations} of stresses and strains in the elastic-plastic range. The calculations were done for each material under bending, torsion and combined bending with torsion. The data in graphs were read out from the selected group of elements placed in one axis in the $\mathrm{XZ}$ plane. In these elements, under the bending and torsion testing a full range of the stress and strain history was observed in the specimen section.

Strain and stress distributions for $\mathbf{C k} 45$ steel. The maximum torsional moment applied during calculations was $M_{s}=120 \mathrm{~N} \cdot \mathrm{m}$. For this moment, the maximum shear stresses in the external layers of the specimen are $\tau_{\max }=330 \mathrm{MPa}$. The maximum shear strains are $\gamma_{\max }=0.027$. The successive increments of the torsional moment show that the distribution of stresses $\tau$ is linear only for the moment equal to $12 \mathrm{~N} \cdot \mathrm{m}$; in the case of further increments the curvature of the stress distribution can be observed. The maximum shear strains have the linear distribution for each value of the moment $M_{s}$. Distributions of stresses and strains for pure torsion are shown in Fig. 2. The maximum bending moment for which the calculations have been done, equals $M_{g}=90 \mathrm{~N} \cdot \mathrm{m}$. For such a moment, the normal stresses are $\sigma_{z}=568 \mathrm{MPa}$, and corresponding strains $\varepsilon_{z}=0.022$ correspond to the values of the cyclic hardening curve of the material. Under bending, the normal stresses are equal to the normal stresses in the $Z$ axis. Linear stress distribution occurs only in the case of low bending moments, for $M_{g}=18 \mathrm{~N} \cdot \mathrm{m}$ we can observe a slow curving of the stress histories. As the moment increases, the curvature takes form of a part of the cyclic strain curve for the values of the maximum normal stresses.

The normal strain distribution in the $Z$ axis keeps a linear character for each loading value. Distributions of stresses and strains for pure bending are shown in Fig. 3. 

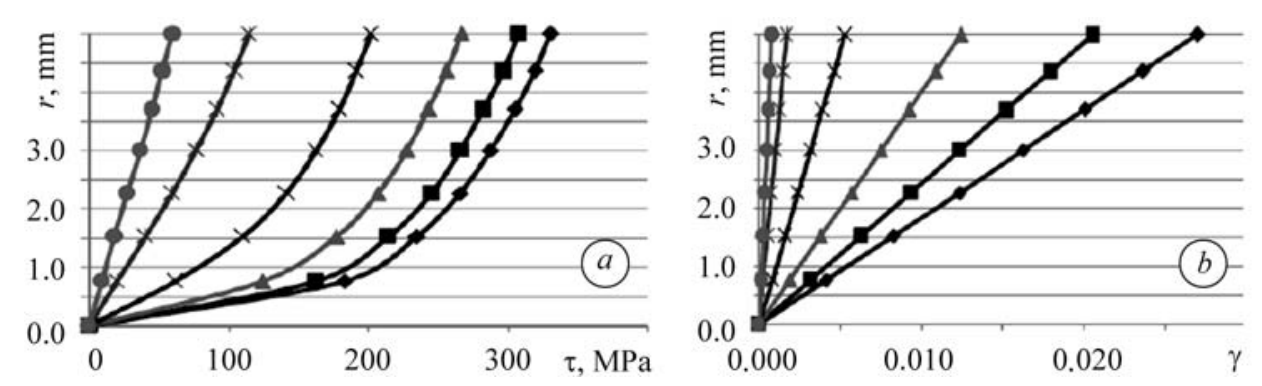

Fig. 2. Distribution of maximum shear stresses $\tau(a)$ and strains $\gamma(b)$. The legend presents values of the torsional moment $(\bullet-120 \mathrm{~N} \cdot \mathrm{m} ; \boldsymbol{\square}-96 ; \boldsymbol{\Delta}-72 ; \times-48 ; \boldsymbol{*}-24 ; \mathbf{O}-12 \mathrm{~N} \cdot \mathrm{m})$ corresponding to each curve (Ck45).
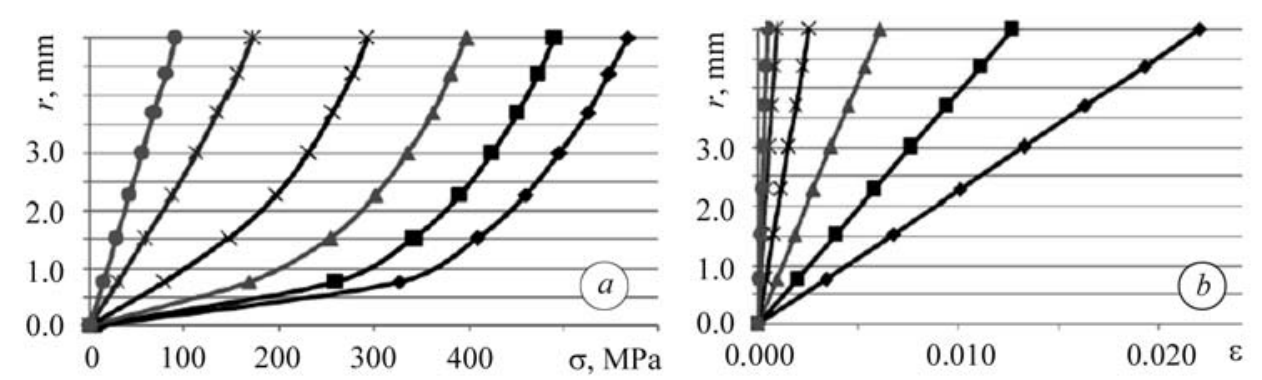

Fig. 3. Distribution of normal stresses $\sigma(a)$ and strains $\varepsilon_{\mathrm{z}}(b)$ of the $Z$ axis. The legend presents values of the bending moment $(-90 \mathrm{~N} \cdot \mathrm{m} ; \boldsymbol{\square}-72 ; \boldsymbol{\Delta}-54 ; \times-36 ; *-18 ; \mathbf{0}-9 \mathrm{~N} \cdot \mathrm{m})$ corresponding to each curve $(\mathrm{Ck} 45)$.

Distributions of stresses and strains for AlCuMg1 aluminium alloy. The maximum torsional moment applied for calculations is $M_{s}=100 \mathrm{~N} \cdot \mathrm{m}$. For this moment, the maximum shear stresses in the external layers of the specimen are $\tau_{\max }=283 \mathrm{MPa}$, and maximum circumferential shear strains are $\gamma_{\max }=0.0297$. The successive increments of the torsional moment show that distribution of stresses $\tau$ is linear only for the moment $40 \mathrm{~N} \cdot \mathrm{m}$, further increments cause the curvature of the stress distribution (for the moment $M_{s}=50 \mathrm{~N} \cdot \mathrm{m}$ curvature of the distribution is observed in the external fibbers). The maximum shear strains have a linear distribution for each $M_{s}$. Distributions of stresses and strains for pure torsion are shown in Fig. 4.
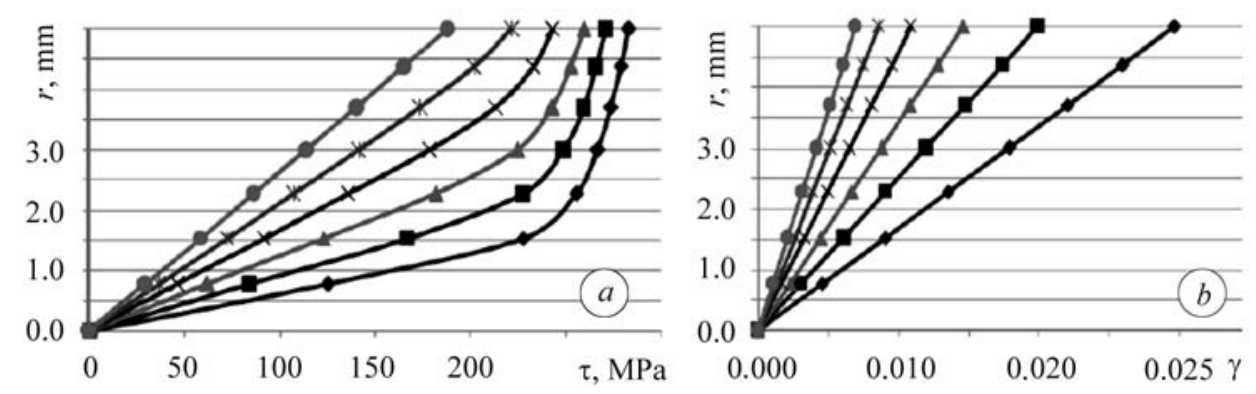

Fig. 4. Distribution of maximum shear stresses $\tau(a)$ and strains $\gamma(b)$. The legend shows values of the torsional moment $(\checkmark-100 \mathrm{~N} \cdot \mathrm{m} ; \boldsymbol{\square}-80 ; \boldsymbol{\Delta}-70 ; \times-60 ; *-50 ; \boldsymbol{O}-40 \mathrm{~N} \cdot \mathrm{m})$ corresponding to each curve (AlCuMg1).

The maximum bending moment for which the calculations were done was $M_{g}=$ $=90 \mathrm{~N} \cdot \mathrm{m}$ and the normal stresses were $\sigma_{z}=472 \mathrm{MPa}$, the appropriate strains $\varepsilon_{z}=0.025$ correspond to the values of the cyclic hardening curve for the material. The linear stress distribution occurs for the bending moment below $M_{g}=36 \mathrm{~N} \cdot \mathrm{m}$, in the case of successive loading increments $M_{g}=45 \mathrm{~N} \cdot \mathrm{m}$ we can observe a slow curving of the 
stress histories. As the moment rises, it takes a shape of the part of the cyclic hardening curve up to the value of the maximum normal stresses. Distribution of the normal strains in the $Z$ axis keeps a linear character for each loading value. Distributions of stresses and strains for pure bending are shown in Fig. 5.
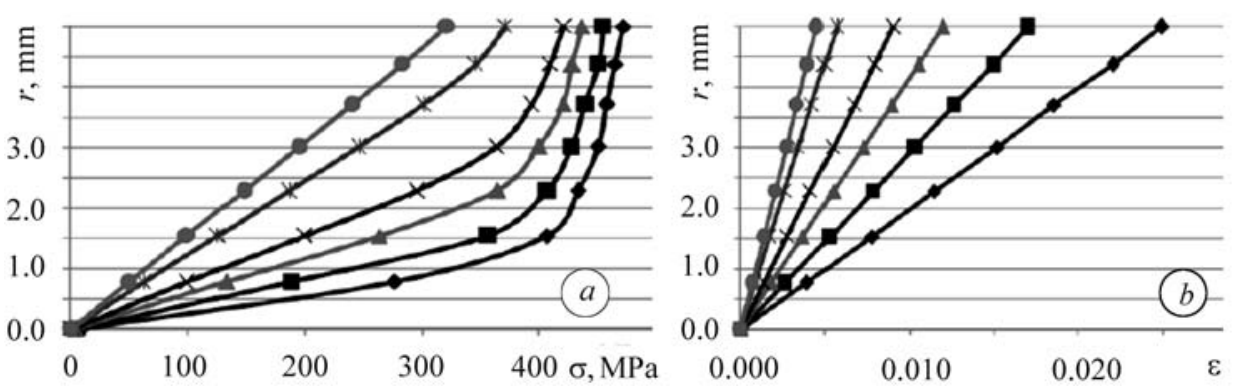

Fig. 5. Distribution of normal stresses $\sigma(a)$ and strains $\varepsilon_{\mathrm{z},}(b)$. The legend shows values of the bending moment $(-90 \mathrm{~N} \cdot \mathrm{m} ; \boldsymbol{\square}-81 ; \boldsymbol{\Delta}-72 ; \times-63 ; *-45 ; \boldsymbol{\bullet}-36 \mathrm{~N} \cdot \mathrm{m})$ corresponding to each curve $(\mathrm{AlCuMg} 1)$.

Distributions of stresses and strains for X2CrNiMo1810. The maximum torsional moment applied in calculations is $M_{s}=90 \mathrm{~N} \cdot \mathrm{m}$. For this moment the maximum shear stresses in the specimen external layers are $\tau_{\max }=275 \mathrm{MPa}$, while the maximum circumferential shear strains are $\gamma_{\max }=0.022$. The successive increments of the torsional moment show that the distribution of stresses $\tau$ is linear only for small torsional moments, above $M_{s}=9 \mathrm{~N} \cdot \mathrm{m}$ there is the distribution of curves and takes a form of the cyclic strain curve. The maximum shear strains are linear for each value of the moment $M_{s}$. Distributions of stresses and strains for pure torsion are presented in Fig. 6.
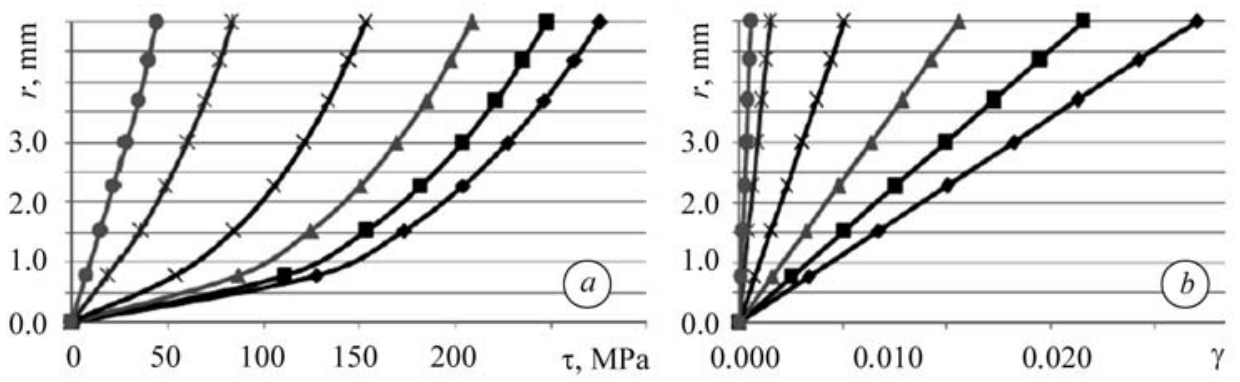

Fig. 6. Distribution of maximum stear stresses $\tau(a)$ and strains $\gamma(b)$. The legend contains values of the torsional moment $(-90 \mathrm{~N} \cdot \mathrm{m} ; \boldsymbol{\square}-72 ; \boldsymbol{\Delta}-54 ; \times-36 ; *-18 ; \boldsymbol{\bullet}-9 \mathrm{~N} \cdot \mathrm{m})$ corresponding to each curve (X2CrNiMo1810).

The maximum bending moment $M_{g}=60 \mathrm{~N} \cdot \mathrm{m}$ was calculated. For this moment, the normal stresses $\sigma_{z}=428 \mathrm{MPa}$, and the appropriate strains $\varepsilon_{z}=0.0124$ correspond to the values of the cyclic strain curves for the material. The linear distribution of stresses occurs for the bending moment below $M_{g}=12 \mathrm{~N} \cdot \mathrm{m}$, for a successive loading increment $M_{g}=18 \mathrm{~N} \cdot \mathrm{m}$ we can observe a slow curving of the stress histories. As the moment rises, the stress course takes a shape of the part of the cyclic strain curve up to the values of the maximum normal loadings. Distribution of normal strains in the $Z$ axis keeps the linear character for each loading value. Distributions of stresses and strains for pure bending are presented in Fig. 7.

Distributions of stresses and strains for SUS 304-HP. The maximum torsional moment applied in the calculations was $M_{s}=50 \mathrm{~N} \cdot \mathrm{m}$. In such a case, the maximum shear stresses in the external layers of the specimen were $\tau_{\max }=140 \mathrm{MPa}$. 

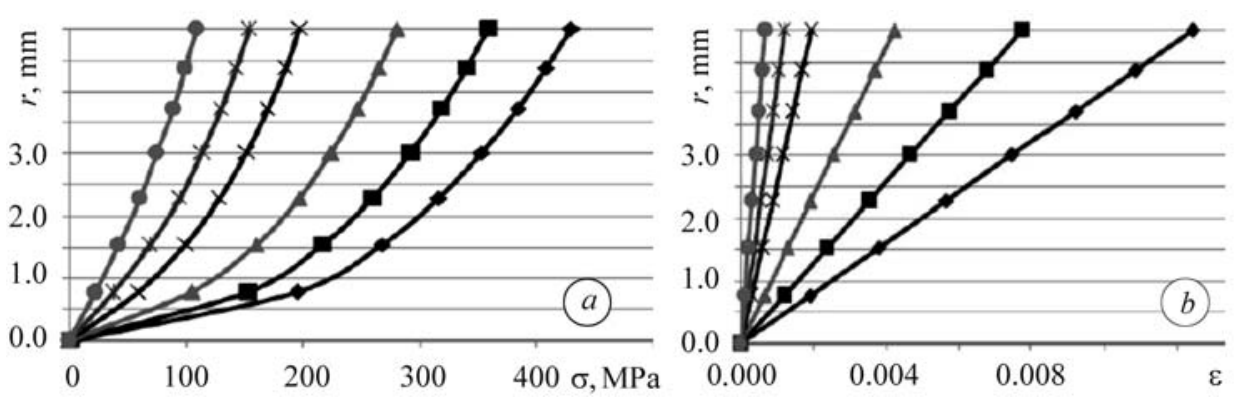

Fig. 7. Distribution of normal stresses $\sigma(a)$ and strains $\varepsilon_{z}(b)$. The legend contains values of the bending moment $(-60 \mathrm{~N} \cdot \mathrm{m} ; \boldsymbol{\square}-48 ; \boldsymbol{\Delta}-36 ; \times-24 ; *-18 ; \boldsymbol{Q}-12 \mathrm{~N} \cdot \mathrm{m})$ corresponding to each curve (X2CrNiMo1810).

The maximum circumferential shear strains were $\gamma_{\max }=0.027$. The successive increments of the torsional moment show that the distribution of stresses $\tau$ is linear only for small torsional moments. Above $M_{s}=10 \mathrm{~N} \cdot \mathrm{m}$ we can observe the curvature of the distribution with a shape of the cyclic strain curve. The maximum shear strains have a linear distribution for each value of the moment $M_{s}$. Distributions of stresses and strains for pure torsion are shown in Fig. 8.
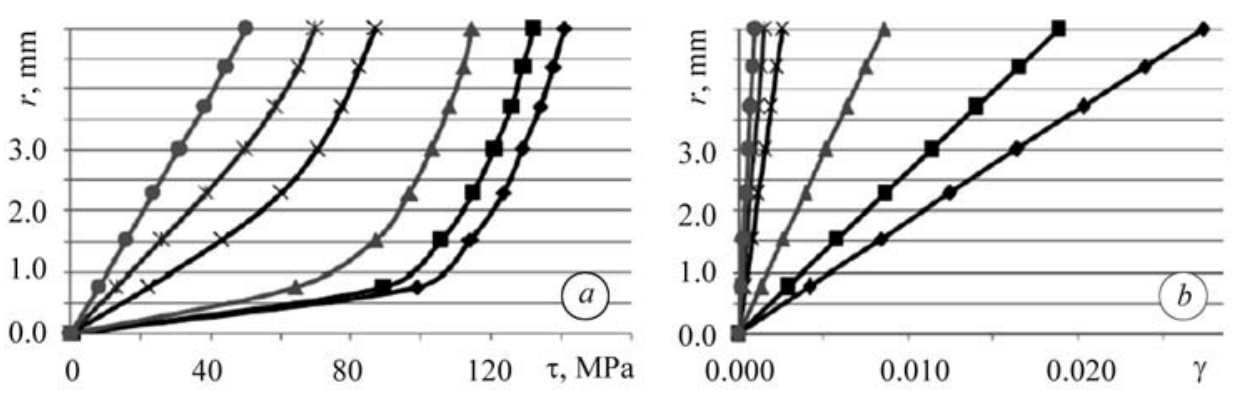

Fig. 8. Distribution of maximum shear stresses $\tau(a)$ and strains $\gamma(b)$. The legend gives values of the torsional moment $(\checkmark-50 \mathrm{~N} \cdot \mathrm{m} ; \boldsymbol{\square}-40 ; \boldsymbol{\Delta}-30 ; \times-20 ; *-15 ; \boldsymbol{Q}-10 \mathrm{~N} \cdot \mathrm{m})$ corresponding to each curve (SUS 304-HP).
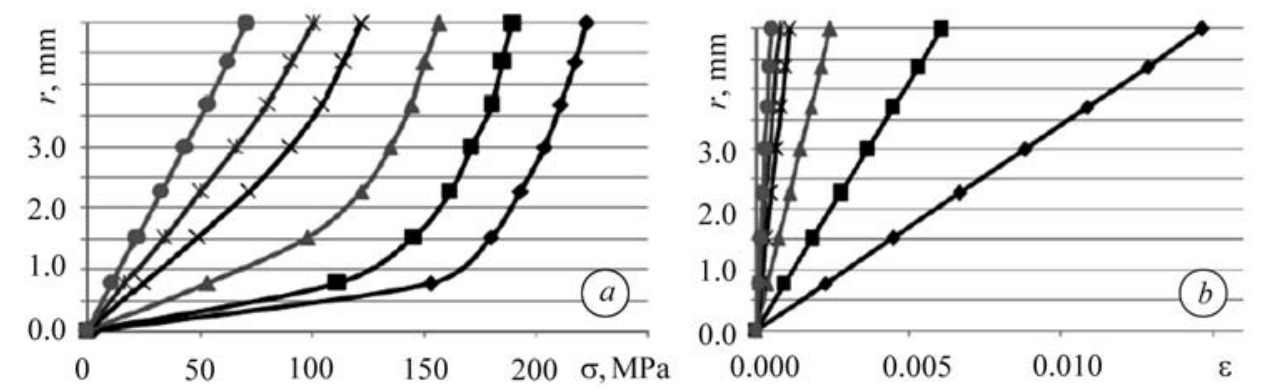

Fig. 9. Distribution of normal stresses $\sigma(a)$ and strains $\varepsilon_{z}(b)$. The legend presents values of the bending moment $(\checkmark-35 \mathrm{~N} \cdot \mathrm{m} ; \boldsymbol{\nabla}-28 ; \boldsymbol{\Delta}-21 ; \times-14 ; *-10.5 ; \mathbf{O}-7 \mathrm{~N} \cdot \mathrm{m})$ corresponding to each curve (SUS 304-HP).

The maximum bending moment was $M_{g}=35 \mathrm{~N} \cdot \mathrm{m}$, for this moment, the normal stresses were $\sigma_{z}=222 \mathrm{MPa}$, and the appropriate strains $\varepsilon_{z}=0.015$ correspond to the values of the cyclic strain curve for the material. Linear distribution of stresses occurs for the bending moment below $M_{g}=7 \mathrm{~N} \cdot \mathrm{m}$; for a successive loading increment $M_{g}=$ $=10.5 \mathrm{~N} \cdot \mathrm{m}$ we can observe a slow curving of the stress history. As the moment rises, it takes the form of a part of the cyclic strain curve for the maximum normal stresses. Di- 
stribution of normal strains in the $Z$ axis is linear for each loading value. Distributions of stresses and strains for pure bending are presented in Fig. 9.

Distributions of stresses and strains for CuNiCr35. The maximum torsional moment was $M_{s}=75 \mathrm{~N} \cdot \mathrm{m}$. For this moment, the maximum shear stresses in the external layers of the specimens were $\tau_{\max }=266 \mathrm{MPa}$. The maximum circumferential shear strains were $\gamma_{\max }=0.014$. Character of the cyclic strain curve for $\mathrm{CuNiCr} 35$ is similar to that of an elastic-perfect-plastic body. As the torsional moment rises, the stresses and strains linearly increase to the value $\tau_{\max }=264 \mathrm{MPa}$ next we can observe rapid breaks of the stress curves and further loading increase is accompanied by an insignificant increase of stresses. The circumferential shear strains keep their linear and constant history for any torsional moment $M_{s}$. Distributions of stresses and strains for pure torsion are shown in Fig. 10.
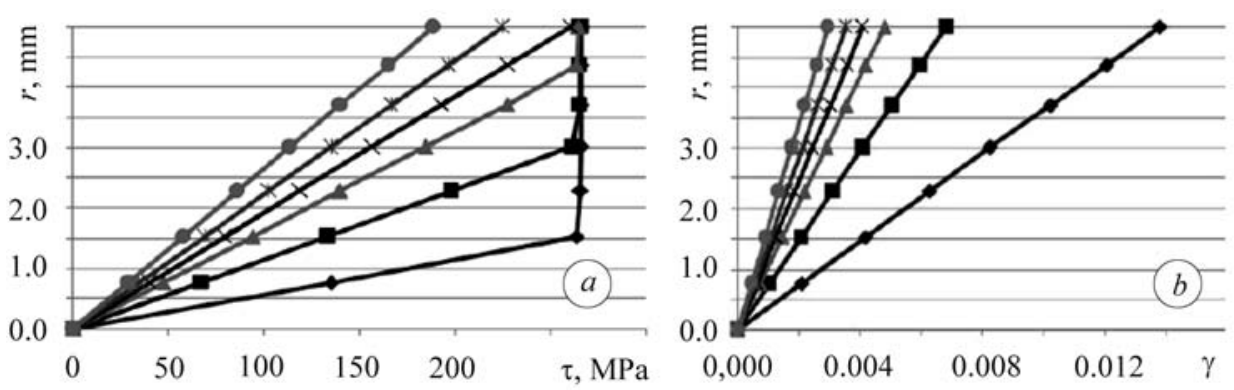

Fig. 10. Distribution of maximum shear stresses $\tau(a)$ and strains $\gamma(b)$. The legend contains values of the torsional moment $(-75 \mathrm{~N} \cdot \mathrm{m} ; \boldsymbol{\square}-67.5 ; \boldsymbol{\Delta}-60 ; \times-52.5$; $*-45 ;-37.5 \mathrm{~N} \cdot \mathrm{m})$ corresponding to each curve $(\mathrm{CuNiCr} 35)$.

The maximum bending moment in the calculations was $M_{g}=75 \mathrm{~N} \cdot \mathrm{m}$. In this case, the normal stresses were $\sigma_{\mathrm{z}}=436 \mathrm{MPa}$, and the appropriate strains $\varepsilon_{z}=0.017$ correspond to the values of the cyclic strain curve for the material. Like in the case of torsion, as the bending moment rises, we can observe the stress increase to $\sigma_{z}=434 \mathrm{MPa}$. The further loading increase causes a rapid break of the stress history. From that moment, the increase is minimum in relation to the increase of the bending moment. Distribution of normal strains of the $Z$ axis $\varepsilon_{z}$ and the maximum shear strains $\gamma$, is linearly independent of the loading value. Distributions of stresses and strains for pure bending are shown in Fig. 11.
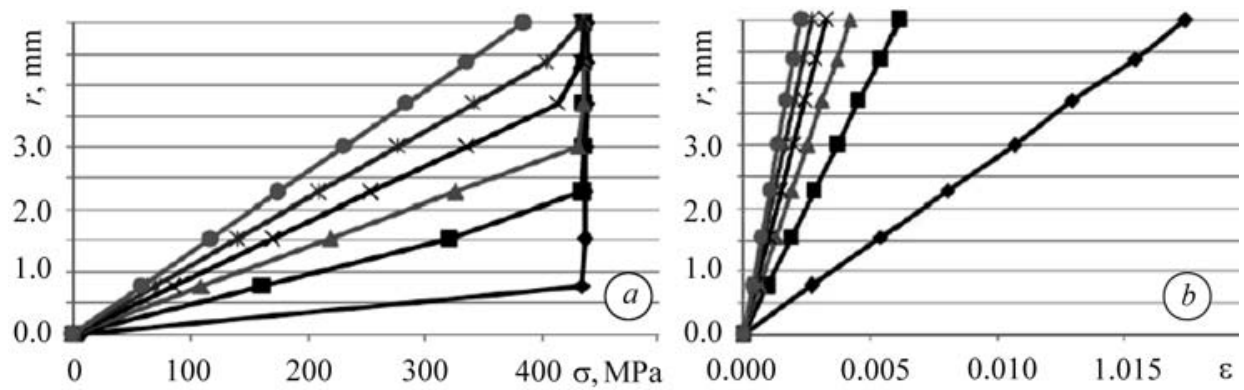

Fig. 11. Distribution of normal stresses $\sigma(a)$ and strains $\varepsilon_{z}(b)$. The legend contains values of the bending moment $(-75 \mathrm{~N} \cdot \mathrm{m} ; \boldsymbol{\square}-67.5 ; \boldsymbol{\Delta}-60 ; \times-52.5 ; *-45 ;-37.5 \mathrm{~N} \cdot \mathrm{m})$ corresponding to each curve $(\mathrm{CuNiCr} 35)$.

\section{CONCLUSIONS}

The paper presents the analysis of the stress and strain distribution in different materials and for different types of loading: pure bending, pure torsion and combined pro- 
portional bending with torsion. The following conclusions can be drawn from the review of the obtained results:

The linear strain distribution was observed for each considered material and each loading. A diversified characteristics of the cyclic strain curve for each material allows as to think that that the strain distribution is linear for any tested material. The stress distribution has the course conforming with the cyclic strain curves applied in the materials analysis; for small loadings the stress distribution corresponds to the linear part of the curve $\sigma_{a}-\varepsilon_{a}$, when loading increases, the stress distribution takes a shape corresponding to the further part of the curve $\sigma_{a}-\varepsilon_{a}$. The non-linear increment of the stresses and strains versus loading can be seen. Each uniform loading increment causes the decrease of stresses and strains increment. The conclusions allow us to verify the known analytical methods of stress determination under pure bending, pure torsion and combined bending and torsion.

РЕЗЮМЕ. Визначено розклад напружень і деформацій в перетині проаналізованого елемента вальців та подано графічно за допомогою комп'ютерної моделі. Аналіз п’яти матеріалів та їх кривих циклічного деформування з різними характеристиками за умов кручення та згину показав лінійний характер розкладу деформацій для кожного з них за всіх прикладених навантажень.

РЕЗЮМЕ. Определено распределение напряжений и деформаций в сечении проанализированного элемента валков и представлено графически с помощью компьютерной модели. Анализ пяти материалов и их кривых циклического деформирования с разными характеристиками при кручении и изгибе показал линейный характер распределения деформаций для каждого из них при всех приложенных нагрузках.

1. Aifaties E. C. Strain gradient interpretation of size effects // Int. J. Fracture. - 1999. - 95. - P. 299-314.

2. Boller C. and Seeger T. Materials Data for Cyclic Loading // Elsevier Publishing Company. $-1998 .-264$ p.

3. Karolczuk A. Nielokalne metody obliczeń zmęczeniowych // Studia i monografie, z. 239, Opole. - 2009. - $120 \mathrm{~s}$.

4. Łagoda T. Modelowanie lokalnych naprężeń i odkształceń w przekroju pręta z karbem przy kombinacji zginania ze skręcaniem // Prace XIX-go Sympozjum "Zmęczenie i Mechanika Pękania”. - Bydgoszcz, 2002. - S. 225-232.

5. Łagoda T., Marciniak Z. Wyznaczanie lokalnych naprężeń i odkształceń sprężysto plastycznych przy zginaniu ze skręcaniem pręta gładkiego // Prace XIX-go Sympozjum "Zmęczenie i Mechanika Pękania". - Bydgoszcz, 2002. - S. 233-240.

6. Rozkłady naprężeń i odkształceń w próbkach gładkich i z karbem przy kombinacji zginania ze skręcaniem / T. Łagoda, E. Macha, K. Molski, R. Ferenc // VIII Krajowa Konferencja Mechaniki Pękania, Kielce-Cedzyna 2001, (Zesz. Nauk. Politechniki Świętokrzyskiej, Mechanika 73). - S. 55-62.

7. Manson S. S. Future directions for low cycle fatigue, Low Cycle Fatigue. ASTM STP 942 / Eds. H. D. Salomon, G. R. Halford, L. R. Kaisand, and B. N. Leis) // ASTM. - Philadelphia, 1988. - P. 15-39.

8. Manson S. S. and Muralidharan U. Fatique life prediction in bending from axial fatigue information // Fatique Fract. Eng. Mater. Struct. - 1987. - 9, № 5. - P. 357-372.

9. Molski K. and Glinka G. A method of elastic-plastic stress and strain calculation at a notch root // Mat. Sci. and Eng. - 1981. - 50, № 2. - P. 93-100.

10. Neuber $H$. Theory of stress concentration for shear-strained prismatical bodies with arbitrary nonlinear stress strain law // ASME J. Applied Mech. - 1961. - 28. - P. 544-550.

11. Sanetra $C$. Untersuchungen zum Festigkeitsverhalten bei mehrachsiger Randombeanspruchung unter Biegung und Torsion, Dissertation, Tech. Universitat Clausthal, 1991. - $151 \mathrm{~s}$.

12. Balytskyi O. I., Ripey I. V., and Onyshak Ja. D. Verification of the impact toughness of $12 \mathrm{Kh} 1 \mathrm{MF}$ steel in operating steam pipelines of thermal power plants // Materials Science. - 2009. - 6, № 45. - P. 826-830. 